\title{
Religion, Violence, Poverty and Underdevelopment in West Africa: Issues and Challenges of Boko Haram Phenomenon in Nigeria
}

\author{
Ani Casimir ${ }^{1}$, C. T. Nwaoga ${ }^{2}$, Rev. Fr. Chrysanthus Ogbozor ${ }^{3}$ \\ ${ }^{1}$ Department of Philosophy, Institute of African Studies, University of Nigeria, Nsukka, Nigeria \\ ${ }^{2}$ Department of Religion, Centre for Entrepreneurial Studies, University of Nigeria, Nsukka, Nigeria \\ ${ }^{3}$ Department of Philosophy, University of Nigeria, Nsukka, Nigeria \\ Email: cepperngo@yahoo.com, nwaogachichi@yahoo.com, emekaogbozo@yahoo.com
}

Received November $7^{\text {th }}$, 2013; revised December $7^{\text {th }}, 2013$; accepted December $14^{\text {th }}, 2013$

Copyright (c) 2014 Ani Casimir et al. This is an open access article distributed under the Creative Commons Attribution License, which permits unrestricted use, distribution, and reproduction in any medium, provided the original work is properly cited. In accordance of the Creative Commons Attribution License all Copyrights (C) 2014 are reserved for SCIRP and the owner of the intellectual property Ani Casimir et al. All Copyright $@ 2014$ are guarded by law and by SCIRP as a guardian.

Violent conflicts in emerging democracies or societies in transition threaten the stability of state governance institutions, which brings about insecurity of lives, property and deepens the vicious cycle of poverty and criminality in Africa. The first responsibility of any government is to provide security of lives and property. At no time since Nigeria's civil war has the country witnessed the resurgence of violence and insecurity that claims hundreds of lives weekly. It is a sectarian insurgence of multiple dimensions. This article makes the case that Boko Haram is not just a religious phenomenon but a reflection of a socio-political, economic and ethnic problem caused by bad governance. As a result, Boko Haram has witnessed a cross-border influence and impact which has expanded its frontiers beyond Nigeria to neighboring countries in the West African region. The theoretical framework employed in this article posits that Boko Haram has its roots fundamentally in poverty caused by bad governance in the Northern Moslem bend, in Nigeria and the West African Region where corruption, human rights violations, marginalization of cultural, political and religious groups have created the situation whereby weak state structures have abysmally failed to deliver on the development promises made during elections. So the emergence of Nigeria's Boko Haram violence, as a result of the street poverty and the rise of unemployed street beggars, popularly known as Almajiris, and their use for electoral and party violence, was encouraged by the neglect and abandonment of the masses by the governors and other elected leaders. The expansion and consolidation of the Boko Haram insurgence to other parts of the country and neighboring West African nations was made possible by the already existing failed state institutions, bad governance and corruption and the existing band of small criminal sectarian groups that depend upon their survival on aids from $\mathrm{Al}$ Quaeda, drug gangs and sea piracy. The religious dimension is a marginal factor fueled by fundamental socio-economic and political variables which have been thrown up in the first place by bad governance and leadership in Nigeria.

Keywords: Religion; Violence; Conflict; Poverty; Bad Governance; Weak Institutions and Underdevelopment

\section{Introduction/Background}

Insecurity of lives and property of Nigerians have pervaded the huge west African country that analysts have continued to point at the insurgence of the Islamic sectarian group known as Boko Haram as the fundamental cause. The sectarian group has continued to mount series of attacks against every symbol of authority from the state, security agencies, religious figures and heads from both Islam and Christianity that the threat of the country's dismemberment becomes a living reality. The violence and killings have dominated mostly the Northern parts of the country and have continued to spread to other parts of West Africa. In its seminal meaning and ideological justifications, the sect hinges its crusade on its ill-conceived belief that "western education is sin". This translates to "Boko (Western European education)" "Haram is sin”) (Anyanwu \& Nwanaju, 2010: 4-5). The causes of Boko Haram insurgence which has continued to spread to other West African countries, making it a transnational violent conflict had been the cause of speculation by scholars in Africa and across the globe. While some scholars like Ewuzie (2012) believe that the phenomenon is a religious and sectarian problem caused by a fringe sectarian questionable interpretation of the basic tenets of Islam, others such as Mohammed (2012) think differently that the insurgence arose from socioeconomic sources rather than religious or ethnic. The deviant behavior of the sect has also called into question the noble role of religion in not only promoting the ideal ethical association between God, man and the society but which according to Uche 
(2007: 390) is seen as a normative institution that commands the worshipper "not to be involved in murder, theft and deviant behavior.

An exposition of the sect's origin and background outlines how the phenomenon of failed leadership and weak institutions in the North Eastern part of Nigeria gave rise to street begging by children, who became unemployed and were recruited by politicians to act as their thugs to carry out mayhem and violence against their political opponents. Having won elections through rigging and electoral frauds using these youths, who were given weapons and ammunitions to fight their political battles during elections in the country, they abandoned them after they won elections into Government Houses (Mohammed, 2012: 7). This situation is worsened by cases of corrupt enrichment and stealing of state funds which demonstrate how institutions of state have failed to live up to their constitutional roles to deliver good governance and the dividends of development to the poor masses whose poverty and destitution had further marginalized them. This exposition of the weakness of the Nigerian state gives an insight into the failure of state institutions and the multiple natures of the factors that gave rise to the phenomenon of Boko Haram. This historical exposition of the multiple factors behind its origin has been well explained by Mohammed (2012: 14):

What is the origin of Boko Haram? It has been there as a religious sect in some parts of the North Eastern Nigeria. Until sometime from 2002 to 2003 they were recruited to help bring some governors to power. In the process they became part of the mainstream of the government. Some of their members became state commissioners and some became advisers. When they came into government they wanted to push their own religious views through. They fell out with their governors along the line since. They complained about corruption, unemployment for youths and lack of development in their areas. It took a very short time for them to run foul of the law in their states. Armed conflicts started, which led to the extra judicial killings of their leader Mohammed Yusuf.

From this analysis, we can see that the Boko Haram phenomenon is a creation of the failure of the elites to establish strong state institutions of democracy and development that will give rise to the delivery of the social contract of development dividends to the Nigerian citizens, most of whom are poor, frustrated and angry with the state of Nigeria. This is especially the case with the Governors of the Islamic northern states where the Boko Haram insurgency was birthed in 2002 as a socio-economic, cultural and religious unrest against the corrupt rulers of state power in Nigeria (Kukah, 2010: 1-9). A philosophical examination of the relationship between religion and violence will also throw more light to the incidence of Boko Haram.

\section{Religion and Violence: A Philosophical Perspective}

Religion has remained a dynamic force in the history of man and society. Religion draws its strength from its potency to induce or bring about change in the attitudes of its adherents, either positively or negatively. According to Anyanwu and Nwanaju (2010: v) “Africa as a continent seems to confirm the long lasting belief that man is deeply religious, because of the plurality of religion and religious beliefs which are found in it; there are moderates and extremists, fanatics and realists, simple minded believers and complex adherents, liberals and conservatives; they all contribute to the multi-religious nature of Nigeria”. However, as a result of the power of religion to influence development in the society, for good or bad, the examination of the link between religion and violence has become relevant at this point. The dialectical link between religion and violence has given rise to the expression "religious violence", which is elaborated in the following definition of the concept as given by Wellman (2004: 291): "religious violence is a term that covers phenomena where religion in its diversity, is either the subject or object of violent behaviors; religious violence becomes then violence covered, motivated or induced by the reaction of adherents to either their own or others' religion beliefs, values, norms, doctrines or set actions". A recent observation has noted that "religious violence is perpetrated for a very large number of ideological reasons and is generally only one of a large number of underlying social and political issues that lead to the unrest in question" (Nayak, 2008: 6). Violence has been defined by Tanner (2007) as "going far beyond (the infliction of) pain and the shedding of blood", arguing that, "although violence clearly encompasses injury to persons or property, it also includes "the forcible interference with personal freedom, violent or passionate conduct or language, (and) finally, passion or fury." Nayak (2008) notes that the word violence, "carries the meaning of physical force, violent language, injury and, more importantly, forcible interference". However, for the purposes of this exposition on religious violence, let us accept a more holistic definition of "violence" as "any action, verbal or nonverbal, oral or written, physical or psychical, active or passive, public or private, individual or institutional, societal, human or divine, in whatever degree of intensity, that abuses, violates, injures or kills” (Terence, 2004: 24). Tanner (2007: 1) and Selengut (2008: 1) defined the relationship between religion and violence as: "jarring" since religion is thought to be opposed to violence: however, the history and the scripture of the world's religions tell stories of violence and war”. This violent dimension to religion has become polemical as violence has been seen as "the inevitable consequence of the irrationality of religious precepts” (Tanner, 2007: 1). So it is logical to conclude that when the true tenets of a particular religion is compromised, abused, misused or wrongly interpreted out of selfish political, socio-economic objectives, as the Boko haram did to true Islamic tenets, then the activities of such sects become irrational, violent or deviant. This could be said for any other religion, not only Islam. Consequently, Hitchens (2007) and Dawkins (2006) have argued and concluded that religion causes tremendous harm and damage to societal development in three dimensions:

1). Religions sometimes use war, violence and terrorism to promote their religions goals;

2). Religious leaders contribute to secular wars and terrorism by endorsing or supporting the violence, and;

3). the fact that religious fervor is exploited by secular leaders to support war and terrorism."

Social scientists such as Pape (2006) after studying the link between religion and violence, has ascribed secular and political motivations behind what people describe as "religious violence. "Pape made a successful case for "secular motivations and reasons as being the foundations of most suicide attacks that are often times labeled as "religious" concluding that "sui- 
cide bombers" actions stem fundamentally from political conflict, not religion. This explains why most informed scholars studying the Boko Haram violence in Nigeria would ascribe political and socio-economic reasons even as some would define it as outright terrorism. To start with terrorism is often hard to define and it is not the object of this article to link the Boko haram violence as such because, according to Ward law (1990: 3) a major obstacle to a definition of terrorism "that commands broad respectability is that, in many instances and contexts, terrorism involves issues of morality. That is, the term terrorist has often been applied to individuals, groups, organizations, nations, and events in a way that involves making a moral judgment, based on the assumption that some categories of violence are justifiable, whereas others are not”. As a result of this conceptual confusion, Vetter and Perlstein (1990: 3) observes that “one man's terrorist is another man's freedom fighter". This is not to say that Islam has not been linked to violence or that the Boko haram sectarian violence is justifiable. Actually, according to Vetter and Perlstein (1990) Islam has been linked to violence under different contexts with jihads (holy war) against perceived enemies of Islam or Moslems, against women's rights as supported by texts quoted or misquoted from Islam. Muslims, including clerics, leaders and the common people have often "used Islamic ideas, concepts, texts, and themes to justify violence, especially against mainstream Muslims and non-Muslims (Omotosho, 2003: 16). Often a misinterpretation of the Koran or any Islamic doctrine could often lead to violence from Islamic adherents under this wrong and negative influence against those people, ideas or institutions perceived wrongly or rightly to be against Islam or Muslims. Socio-economic, political cultural, environmental and secular factors could aggravate religious violence while fundamentalism and extremism could become substantial explanations for its emergence. Thus one could safely conclude that it is not the true nature of the religion that causes the sectarian violence (though it is factor) but other factors are used by the group causing the violence to hide under religion. If for example one is ignorant of a religion and its true tenets and causes violence in the name of the religion then one should look elsewhere for the substantial reasons that motivated the group to violence. This interpretation could lead to a situation whereby other religions, for example, Christianity is interpreted as representing the pillar and source of western values and western education. Hence when this wrong construction seizes a group such as Boko haram in Nigeria and drives their violent behavior, the sect would see western education and values as representing Christianity. Such an error in interpretation is what Huntington (1996: 245) and Samir (2008: 2) would respectively and rightly describe as "clash of civilizations" and the cause of "existing frictions between Islam and the West, the latter, to a certain extent, being an allusion to Christian culture and values”. This explains the multi-faceted nature of the causes of both intra and inter religious violence in Nigeria, especially the Boko haram violence. Omotosho (2003: 15-31) also agrees with this multifaceted nature of the causes of religions violence, especially in Nigeria with the following observations:

Many factors are responsible for religious violence in $\mathrm{Ni}$ geria. However, in order to do justice, it will be proper to classify these factors according to the nature of the violence. As already pointed out, Nigeria has experienced both intra ad inter-religious violence. In the case of intrareligious violence, two major reasons can be identified.
Firstly, there is ignorance or half knowledge of the true teaching of the very religion that the people involved claim to be defending. For example, if Maitatsine had been well inform enough in Islamic teachings, he would have realized that at no time did the Prophet or his companion attack anybody who has declared himself as Muslim. He would have realized also that gentle persuasion is more effective in making people observe the true teaching of religion than force, as is enjoin by the Qur'an: “Invite (all) to the way of thy Lord with wisdom and beautiful preaching: and argue with them in ways that are best and most gracious'. The second reason is the economic factor as a cause of religious violence in Nigeria. In spite of the fact that the country is blessed with both human and natural resources, the gap between the haves and the have-nots is ever on the increase and this has led to frustration and disillusion among average Nigerians on the lower side of the economy. While many of them turn to outright criminal activities, many others turn to churches and mosques. That has also led to a proliferation of churches and mosques having extreme tendencies.

Kukah (2010), recently reflected upon the Boko haram religious violence in Nigeria with its sectarian disturbances as "going beyond the religious. It was also political and economic. It portrayed the general frustration of citizens with the Nigeria state, its bad government, corruption, and lack of security." Boko haram (Anyawu and Nwanaju (2010: vii) is seen as "meaning that Western (European) education is sin or evil;" Boko haram sect is against everything that comes from, is related to, or is a product of western educational system. Thus the religious sect is against everything that has to do with schools, the state government, universities technology and businesses conducted under the framework of European educational system, values or mores such as banking, stocks etc. Every other institution, organization or groups that work to develop the Nigerian society and people has been wrongly labeled as the athlete or by product of western Europe. Any such institution that promotes values, principles, politics, views, values, doctrines or path of pro-western development has been attacked or destroyed by Boko haram in Nigeria and its surrounding West Africa countries. The United Nations building at Abuja, seen by them as the bastion of refined western education values for human development in the country, was bombed and several personnel of the global body were killed by Boko Haram suicide bombers. The Boko Haram sect and its members are angry that poverty, corruption, bad government, lack of security, human rights abuses, social injustice, imbalanced federation, and other indices of social contradictions in the Nigerian state that have made the people of Northern Islamic extraction not to experience the development dividends arising from their membership of the Nigerian Federation. These contradictions had been exploited by the new Islamic sect to perpetrate violence against the Nigeria state under the guise of Boko Haram. The Boko Haram as an incidence of religious violence has undermined the potency of the Nigerian state towards self development and worsened the status of its weak institutions. This has painted Nigeria as a failing state and has constantly worked to sabotage its development policies, programs and outcomes. All these negative consequences of under development, in the eyes of the Boko Haram, were caused by leaders of state who are the products of western education. Accordingly, the persistence of the corrupt state of the country could only have come from the 
corrupt leaders and the institutions related to them. These corrupt leaders could only be dethroned, as they reasoned, when they are either killed, bombed or Nigeria, as nation, converts to an Islamic state (Anyanwu, 2010: 8-9). These facts were further buttressed by a sliding carried out by nether Hassan Kukah (20191-30) who made the following analytical and apt observations in this direction:

Clearly, in the sectinenbers the persistence of corruption, collapse of public morality, injustice and so on could only be attributed to those who govern in their reasoning, those who govern us do so because they have acquired their tools by gaining western education. These sane people, in their eyes, call themselves Muslims but they persist in things that are haram, "impermissible in Islam. Therefore, as their arguments go, it is their acquisition of western education that has polluted public morality. This may have sounded superficial but this line of thinking had resonance among the poor and western education is considered to be jale, a service and cause of corruptive. They are angry over the fact that their own religious leaders have come under the contrive of the state and are unable to give voice to their pain and suffering. As such, their rebellion is both against the state and leaders of their own faiths. Unable to acquire the tools of modernization, they have remained largely outside the loop of power. Even in the inner successes of their own major cities in the entire region, almost all forms of businesses are conducted by people they considered foreigners. These are almost all southern traders and they are almost all Christians too. Sensing that they have become too weak to lights people like mallam Mohammed Yusuf, the leader of Boko Haram took advantage of this situation by arguing that turning inwards, away from contamination, was a greater source of strength than looking outwards by means of acquiring western education and other tools of modernization. Naturally, for over $90 \%$ of his followers with no western education and graduates of the Islamic education system, this would have node a lot of fuse. In an environment where even the few western educated Muslims have no jobs, this message exposing the underbelly of the state had great appeal. Their new communities became their new family which offered them hope, security and welfare. The Boko haram community becomes an alternative state and their leader an alternative to the failed political class in Nigeria.

The Boko haram is a religious phenomenon that was caused and sustained by poverty with other related socio-economic and political contradictions of a failing state institutions, contradictions that constituted themselves into a dynamic framework of antithesis to development in Nigeria and other West African countries. An elaboration of these factors and variables that have informed these socio-economy political, cultural, secular and religious contradictions and convulsions that are embodied in the phenomenon known as Boko Haram will be undertaken next.

\section{Causes/Factors/Variables}

As could be discerned from the philosophical, analytical and historical exposition given above the Boko haram phenomenon is a result of multiple factors which gave rise to, expanded and consolidated it as a consummate threat to the stability and security of not only Nigeria but other satellite West African countries such as Chad, Togo and Niger. An attempt will be made to identify the different factors and variables that gave rise to it in West Africa. The Boko Haram, as a specie of religious violence, has been traced to several factors such as poverty, imbalanced federation, social injustice, political godfatherism/corruption of the Nigerian political class; intra and inter class conflict; inter and intra party conflict; religious extremism; inter and intra religious conflict; wrong religious education and indoctrination; absence of human values; politicization of religion; religionization of politics; bad governance and failed state institutions.

\section{Poverty}

Nigerian poverty situation has been described as an embarrassment and irony to her abundant natural resources buoyed by oil wealth discovered since 1953 . Poverty has led to frustration and anger amongst the poor and the marginalized cultural and religious groups in the country. Poverty among the unemployed youths in the North fuelled by corrupt Northern leaders has been identified as cause of the Boko Haram violence. Most of the recruits used by the sect as members and suicide bombers are drawn from the former Almajiris (poor street children, from poor Muslim parentage, who had been denied formal Western education but had been exploited while growing up by rich Islamic clerics who use them as street beggars to ask for alms on the streets of Northern Nigeria. The Boko haram sect usually offers food, shelter, security and alternative succor to these homeless children and youths to get their support.

\section{International-The Returnee Arab Spring-Fighters/Al-Quaeda Influence}

The Returnee Arab spring-fighters who returned and ran away from Libya as the after effects of the Arab spring in that country and the take-over by Libyan transition forces joined the Boko haram group in Nigeria ,giving rise to a more strengthened army of deviants and with more arms, money, expertise in bomb manufacture, al-Quaeda connections and insurgency. This is why some researchers such as Oluwagbemi (2012: 13) concluded that the Boko haram is a local yet global phenomenon that needs more extensive study.

\section{Imbalanced Federation}

Orji Uzor Kalu (2012: 71) has argued that the Boko Haram menace is to be traced to the shaky foundation of Nigeria's federalism since independence: "the reason for the continual crises besetting our nation is simple-the foundation on which our independence and federalism were built was faulty. This is evident in the crisis that almost scuttled the effort to build Nigeria into one united, indivisible nation”.

\section{Social Injustice}

Orji Uzor Kalu (2012: 71) has equally traced the origin of the Boko Haram incidence to the existence of sufferings and social injustice in the land. Several groups and organizations have suffered injustice in the hands of the Nigerian state with many claiming marginalization from the corridors of power and distribution of state resources. Those who felt that they were unjustly treated by the Nigerian state have always rebelled against 
the state. Biafra rebelled under the weight of in justice; Niger Delta did same; the north, this theory claims, came out, under Boko Haram, to rebel against the injustice meted out to them when the presidency was denied to them through party and electoral manipulation by the southern politicians.

\section{Political God-Fatherism and Corruption of the Nigerian Political Class}

Nigeria is in democracy but the political space has been deliberately restricted and occupied by selfish and corrupt elites who are used to power and would not want the younger educated elements to enter the space to participate in democratic activities. Only these favored political group members and their cronies who are ready to compromise the interests of the people and compromise state institutions are allowed by god-fathers (older and richer but corrupt political elites) to participate. This has given rise to political frustration on the part of youths from the northern Islamic states in Nigeria with its attendant violence from marginalized Northern youths grouped as Boko haram.

\section{Intra and Inter Class Conflict}

The political elite in Nigeria is made up of an active upper class and a vanishing middle class. The majority and the poor are outside the loop of power. The middle class, pushed down to become part of the lower rungs of political thuggery resorted to violence, using the Islamic sect to fight the upper class who have denied them power. The infighting between the elite political classes has also made them to resort to enlisting the help of the marginalized and frustrated lower classes to fight themselves for political space. This variable has made militancy possible and sustained not only in the Islamic North but also in the south as different militant groups have come up in Nigeria such as MASSOB, OPC and the Niger Delta all with a common ambition to make the country ungovernable.

\section{Intra and Inter Party Conflict}

The contest for political space often rages on not only inside political parties but also between registered political parties where the struggle for power and the resources has been described not as a fair, peaceful and open contest but a "do or die affair". The allure of state power and its oil resources that come from electoral victory makes pre and post election activities in Nigeria to be violent and vicious. The fears expressed by international observers and the European Union for the Nigeria's 2011 presidential election became confirmed when Boko Haram insurgency manifested in the political space of Nigeria, as soon as the 2011 elections ended and president Goodluck Jonathan, a southerner, was elected president of the country when the North expected one of their own to be the elected one.

\section{Religious Extremism/Inter-Religious Conflict}

Tunde Babawale (2010: 91) has observed that history has shown that in our contemporary world, conflicts and wars can occur on account of religious differences. Eme (2010: 91) has equally observed that "such conflicts occur when there are divisions caused by differences in religious beliefs. Nigeria is replete with such religious differences which have led to tragic violence that has killed innocent people, destroyed properties and dislocated whole communities in different parts of the country.
The Boko Haram insurgence is conflict between a particular Islamic sect and the rest of the Nigerian Christian community who felt that they will be affected if the agenda of the sect to Islamize the whole country comes to pass. In a situation where there are $45 \%$ Christains, $49 \%$ Moslems and 9\% traditional worshippers, for a tiny sect made up of 3\% of the Muslim umah in Nigeria (Facts and figures about Nigeria: 2009) to insist that the other 53\% (Christians and traditional worshippers) and the 49\% mainstream Muslims must become and convert to their brand of Islam is wrong-headed extremism and intolerance of other faiths. Religious difference, which could be fired by extremism and intolerance, could often lead to religious conflict. According to Eme (2010) religious conflict could be caused by the "inability of a society or a particular religion(s) to understand and harmonize conflicting issues with other religions (inter-religious conflict), while the other is a function of the diversity of doctrinal interpretations within the same religion (intrafaith conflict). Thus we could say that Boko haram is caused by intra and inter religious conflict brought about by religious extremism and intolerance

\section{Wrong Religious Education and Indoctrination}

Religious fundamentalism has been ascribed as a major cause of the Boko Haram insurgency in Nigeria. However, fundamentalism is a function of wrong religious education and indoctrination that teaches the wrong or adulterated principles of the founder or mainstream faith of a religion. The danger is that the adulterated teachings are often passed off as the right or pure path without the adherents of the extremist sect knowing any better. Boko haram is a direct consequence of the teaching of the wrong version of Islam. Boko haram forces and abducts Christians to become Moslems and also kills them. Islam does not force nor compel others to become Moslems. As rightly observed by Anyanwu (2010: 34-35):

Religious fundamentalists of every hue should be reminded that conversion can only be induced by proper teaching not violence. Forcible conversion is opposed to freedom of religion which is an inalienable fundamental human right. The scriptures of the world religions, including Christianity and islam, acknowledge that people should be left free to embrace or not embrace religion

\section{Absence of Human Values}

Human relationships in Nigeria were becoming increasingly materialistic with the loss of human values. People were becoming more materialistic and desperate to survive as a result of the economic depression and mass destitution caused by repeated failure of state reforms and elite corruption. People wanted to get rich quick and get out of the poverty net in Nigeria which was affecting over $65 \%$ of the people (Facts and figures about Nigeria: 2009). All sorts of criminality were resorted to-advance fee fraud, kidnapping, white collar crime, drug trafficking and examination malpractice and human trafficking. According to Bhagawan Sathya Sai (1965: 21) the degeneration in the society emanates from the theory of human values - truth, peace, right conduct, non-violence and love-when human values become absent in human affairs and relationships, the members of the society, rather than aspire to become moral heroes slide into immoral zeros. As a result of this ethical slide, the average Nigerian would just want to become rich without con- 
textualizing human and ethical values as part of the process of making money and becoming wealthy. In other words, the end justifies the means. The absence of these values has made the country an environment for the growth of Boko Haram insurgency and violence.

\section{Bad Governance/Failed State Institutions}

Boko haram, with its sectarian violence, is perceived to be symptomatic of the angry reactions of a frustrated citizenry who are not happy with existing bad governance and the failed state institutions that have bred criminality, poverty, lawlessness and insecurity. The vacuum created by the failure of governance and its institutions must have made the sect want to create an alternative Islamic state in the Northern part of the country where governance has failed to deliver the dividends of both democracy and development to the people. This view is collaborated by Kukah (2009: vii) who urged the Nigerian ruling class to "fill the vacuum-failure of governance-which has engendered lawlessness and criminality, and which is often mistaken to be religious crisis or conflict.

\section{The Ambiguity of Nigeria's Secularism}

Nigeria is supposed to be a secular state without any state religion or any religion as adopted as a state's own religion. In fact, the constitutional secularity of Nigeria is buoyed by the relevant sections of the Nigerian constitution that allow each citizen the fundamental human right and freedom to worship in accordance with the faith that is acceptable to the person. According to article 38 (p. 36) of the 1999 federal constitution of Nigeria, this freedom of religion says: "Every person shall be entitled to freedom of thought, conscience and religion, including freedom to change his religion or belief and freedom (either alone or in community with others and in public or in private) to manifest and propagate his religion or belief in worship, teachings, practice and observance”. In spite of the solidity and documented legal status of this religious secularity and freedom of the Nigerian citizen to exercise this human right, the state has often meddled and adopted different religions as state business (Omotola, 2009: 81-89). The Nigerian state, at the federal and state levels, had been sponsoring Christians and Moslems to different pilgrimages to either Mecca or Jerusalem using the state resources and funds that belong to Nigerian citizens who belong to other religions. In 2003, the Zamfara state Governor adopted Islam as the religion of the state against the constitutional provisions of secularity that warn against the adoption of any religion as state religion. This ambiguity has penetrated the attitudes of religious groups who felt that they can get away with any public behavior threatening the secularity and freedom of the Nigerian state. Boko haram thus emerged to test this ambiguous position of the Nigerian state to declare that they want to Islamize the entire country.

\section{Politicization of Religion and Religionization of Politics}

The politicization of religion is what I have called the incidence whereby in Nigeria people use the religious space, churches or mosques or any religious fora to achieve the selfish goals of politics or politicians. On the other hand, the religionization of politics is the use of politics and its space and the state to achieve the selfish goals or ambitions of religious sects, clerics and leaders. The zoning of the presidency to the south south and frustration of the northern expectation in the outcome of the 2011 presidential elections gave an opportunity for religious politicians and political clerics to make the Nigerian state ungovernable. This political angle to the Boko haram violence has been documented by various scholars who made the following imputations bordering on what I have earlier designated as the "politicization of religion and the religionization of politics". The threat by General Buhari, a retired northern Muslim, to make Nigeria ungovernable if he loses the 2011 elections coincided with the period when the bombing campaign of the Boko haram sect came upon the scene (Ismail, 2012: 8).

\section{Negative Manifestations/Impact of Boko Haram to Nigerian Development}

The Boko haram violence has drawn back the hands of the clock in Nigeria's national development. Some of the identified negative impacts of the sectarian violence is noted below.

\section{Insecurity of Lives and Property}

The insurgency has led to the loss of six thousand lives and the destruction of thousands of government structures, churches, mosques and sundry properties invested as holdings by the private and public sectors of Nigeria's economy. According to Anyanwu (2010: 127-129)," many lives and properties are lost during the killings, bombings, destruction and confusion arising there from. Those who lost their lives or properties are either innocent citizens or members of the Boko haram sect". Nigerians who live in the North where the insurgency is heaviest are moving down to the Christian South for safety and security.

\section{Discouragement and Loss of Foreign Direct Investment}

Since the return of democracy in 1999, Nigeria has continued to search for the best ways of attracting and increasing foreign direct investment to boost the domestic economy. This vigorous chase for foreign direct investment is seen as a boost for its democratic stability and economic security that will qualitatively and quantitatively to enhance the dynamism of its poverty reduction policy and wealth creation goals for its impoverished citizens. Since the Boko Haram insurgency started, foreign direct investment has become a direct victim of the environment of insecurity. As well argued by Larry Esin (2012), the dismal success of the country's efforts to attract foreign direct investment "can be linked to the unstable political environment caused by Boko haram”.

\section{Destruction of the Economic Prosperity of the North}

As noted by Ochei (2012: 3), since the establishment of the first sharia state of Zamfara, Northern Nigeria in 2000 and the beginning of the Boko haram insurgency in 2003, there had been massive destruction of lives and properties of both Muslims and Christians, especially those in the northern part of Nigeria. This has created an environment of fear, insecurity and loss of interest by investors to invest anew, renew or retain their investment in the northern part of the country. Investors are now moving down to the Southern Christian States where they perceive that their economic investments, properties, assets and 
lives are secured and protected.

\section{Destabilization of Nigeria's Fragile Unity and Stability}

One of the negative impacts of the Boko haram violence is that it has led to constant threats to Nigeria's fragile unity and peace with the fault lines of disintegration emanating and growing daily along religious, tribal and ethnic lines. Renewed calls for secession have increased since the phenomenon started from different parts of the country threatening Nigeria with dismemberment of her Federation.

\section{Inter-Religious Violence and Religious War}

The Boko haram has become known as a fringe Islamic sect brought into existence principally by the political and the socio-economic motivations for survival. Therefore it is not to be considered to be true Islam (Anyanwu: 29) since it professes and carries out violence both against Muslims and Christians. Despite the fact that the sect attacks both Muslims and Christians, the emergence of its violent campaigns have set the two major religions against each other with resultant clashes erupting as community conflict between cattle rearers of Fulani/ Muslim faith against their host Christian communities. This communal clash, which constitutes a dangerous trend that could lead to religious war in the country, would deserve a more detailed treatment as a negative impact.

\section{Calls for Sovereign National Conference and New Federation}

All aspects of the present Nigeria's federal experiment is being called to question by regional groups who want more restructuring and redrawing of the federation. Such include the calls by the Nigeria Governors' Forum for State Police Force and the introduction of community policing to bring the experience of community policing to the grassroots to contain the Boko Haram and other threats to national security, order and stability of the country as such communal sectarian skirmishes are simultaneously taking place in the North, Middle Belt, South East and the South of Nigeria.

\section{Militarization of Nigerian Society}

The phenomenon of soldiers parading the streets have become a permanent feature of Nigeria's civil society with soldiers and the retinue of the defense community-the navy, air force, civil defense, the police-becoming part of the daily fare served to Nigerians a they go about their business. Artifacts of violence such as bombs and small arms have proliferated with a heavy movement and importation of weapons of destruction entering the country since the past three years since the insurgence started.

\section{Conflict between Fulani Cattle Rearers and Host Indigenous Communities in Nigeria's South and Middle Belt}

A dimension to the insecurity in Nigeria has been introduced with the Fulani-settler-hosts community indigene conflicts manifesting in the middle belt and the southern part of the country. In Jos, for example, the bombs and the killings have been traced as the insider works of the Fulani Islamic insurgents who had been embroiled in decades hostility with the their indigene host Christian communities. In August, 2012, another theatre of this conflict manifested in the Ikwerre community, River state of the Niger Delta when Fulani cattle men ransacked and occupied the traditional farmlands of the people, destroying their farmlands, fishing streams, killing the villagers and raping their women and girls (Ani, 2012: 57). The following poignant expositions made by Sunday Ani, a journalist who witnessed and interviewed the victims in the Ikwerre community is relevant in showing how the present book haram incidence has spread nationwide:

They (Fulanis) came, innocently as it could be and they were grazing their cattle without problems. But that was not for long, according to the Ubima community in Ikwerre local government area of river state. These Fulani cattle rearers soon began to terrorize the community. Trouble started when three years ago when the herdsmen invaded their farmlands with their cattle. They started with grazing in the community farms and stealing animals caught in the traps set by the village hunters. Soon they started raping the women who went to the farmlands unaccompanied by the men. Unable to stomach their excesses of the Fulani herdsmen any longer, the villagers are spoiling for war”.

\section{Disruption of the Primary/Secondary School Calendar}

Boko haram has led to the closure of schools not only in the northern part of Nigeria but also in some parts of the country where pupils and students have been forced to close schools to avoid their schools being attacked by gunmen or bombers who are against western education. The incessant attacks by the sect in schools and the constant closure of public schools, as a result, are damaging the future of education and pupils as people no longer feel secured in their learning environments (Omokhunu, 2012).

\section{The Slide into Anarchy-The Somalization of Nigeria}

Ewuzie Alvan (2012, 23) paints a painful picture of how the Boko Haram incidence is quickly leading international observers of emerging conflicts to draw parallels between the state collapse in Somalia and Sudan to Nigeria's slide into anarchy thus:

"In a seemingly innocuous statement tucked away at the periphery of a piece on 'Africa's Next Big war', a referral to the brewing fresh combat in Sudan, the Economist magazine described Nigeria as "volatile". The press across the globe, for good reasons, never ceased to address Nigeria in that garb... For long historians have held that badly drawn imperialist borders that cut across tribes or lumped too many diverse people unhappily together have fuelled violence in many African countries. The foregoing has tended to stir divisive tendencies in Sudan. The predominantly Muslim North and the largely Christian South have been on tenterhooks for decades, fighting a war of that wasted two million people... Nigeria is heading the way of Sudan. Seemingly intractable security issues have lent 
credence to this submission...There have been mass insinuations that the security infractions, largely hedging on religious dichotomy may well be a tussle for power. Question shave hung in the air why bombs did not explode until power changed hands? The international media lately linked the dreaded Al-Quaeda, long listed as a terrorist group, to the inflamed insecurity problems. How come it chose to have links in Nigeria this late in the day? Those are mere academic questions. There are may be more than meets the eye in the matter but the consequences have continued to turn Nigeria into another Sudan”.

Furthermore, Oluwagbemi (2012) makes the following observation: Nigeria, given the Boko haram scenario, may be looking at the slow motion of the balkanization of Nigeria as predicted in 2015 by the Central Intelligence Agency”.

\section{Recommendations}

Religion is a force and influence for good, positive development and peace in the society leading to the cultivation and practice of refined human values and growth of tolerance in human relationships. The impression of religion as a phenomenon of violence and destabilization in Nigeria as Boko Haram is not only a wrong concept, an abuse and misuse of religion for socio-economic and political secular causes, but it is also a wrong conception of Islam (Kukah, 2010: 8; Nwanajah, 2010: 121) as the sect's doctrines that hated everything western education is not true Islam: rather they are using Islam to fight their socio-economic, political, tribal and cultural frustrations, marginalization and injustice brought upon them by the failing Nigerian state system. This wrong impression of religion and Islam in Nigeria by Boko Haram needs to be deconstructed. The recommendation made by this article will centre on the reconstruction of the positive role religion can play in national development and the need to reconstruct Islam as religion of peace and human development which is in tune with Western education. Having established those facts, the research work recommends the following approaches as sustainable solution to the Boko Haram religious violence in Nigeria:

1. Enthrone Good governance and state reforms

2. Poverty reduction must be consistent and be productive of results

3. Start the process of State/Boko Haram dialogue

4. Design an Amnesty program for Boko Haram members

5. Build a policy of Inter-religious and intra-religious harmony that will start with primary schools and permeate all sectors of the economy and culture

6. Establish a program of free western education for youths in the north-targeted at children of Boko Haram and other Islamic sect members coupled with nomadic education(Islamic values as curriculum content);

7. Bring to an end the Nigerian State-inspired Human Rights Abuses;

8. Reconstruction of Islam by the Nigeria's Islamic leaders (To correct the wrong impression that Islam is against Western education or its values such as technology etc.);

9. Closer policing of Nigeria's borders with other countries in West Africa;

10. Constitution of a sovereign national conference to redress the injustice against minority groups and cultures;

11. Eradication of corruption and the sanction of corrupt leaders.

\section{Conclusion}

"Religion, according to Tunde Babawale (2008: 50), has left people badly divided and deeply embittered towards one another". Rather than be a force for negative influence or violence that undermines development, it should be a useful vehicle for the sustainable development of the Nigerian people and society. In fact, as equally argued by Eme (2010: 90-100), quite unlike the destabilizing impacts of the present Boko haram, Nigeria owes a great percentage of its present state of development to the influence of religion. It therefore becomes worrisome that religion is now being associated with conflicts rather than progress. From a multi-dimensional perspective, religion is only marginal to the substantial socio-economic factors and variables that gave rise to and fertilized the emergence of Boko Haram religious violence. Intra and inter religious dialogue between the various stakeholders and the intense implementation of socio-economic and democratic reforms that will strengthen the state and democratic institutions, leading to the delivery of the dividends of democracy and development to the poor Nigerian people is the solution that will reduce tension, conflict and bring about reconciliation. This enabling environment of poverty reduction, good governance, strong state institutions and citizenship dialogue is what will bring about a sustainable solution to the Islamic violence and insurgency against the Nigerian state and its citizens.

\section{REFERENCES}

Ani, S. (2012). Terror in rivers community. Insight, the sun special investigative series. 57.

Anyanwu, S. O., \& Nwanaju (2010). Boko Haram-religious conflicts and dialogue initiatives in Nigeria. Owerri: Edu-Eddy Publications.

Bhagawan, S. S. (1965). Human values and character building. Special divine discourse. Bangalore, 21.

Esin, L. (2012). Foreign direct investment and its discontents. 9.

Ewuzie, A. (2012). Sudanising Nigeria. Daily Sun, 10, 23.

Facts and Figures about Nigeria (2010). Thomas Semene Publishers, Nembe, Yenogoa.

Hitchens, C. (2007). God is not great.

Huntington, S. P. (1996). The clash of civilizations and the remaking of the world order. New York: Simon and Schuster, 245.

Imo, C. O. (1995). Religions and the unity of the Nigerian nation. Uppasal: Almqvist and wisksell International, 21-22.

Ismail, O. (2012). How Chadian and Nigeriens invade Nigeria. Sunday Sun Newspaper, 8.

Kukah, M. (2010). Culled from Anyanwu.

Nayak, A. (2008). Crusade violence: Understanding and overcoming the impact of mission among Muslims. International Review of Mission (World Council of Churches), 97, 386-387.

http://dx.doi.org/10.1111/j.1758-6631.2008.tb00645.x

Ochei, V. O. (2012). The challenge of security in Nigeria, the prospects of state police. Lecture Delivered at the Institute of African Studies, Nsukka: University of Nigeria, 3.

Oluwagbemi, M. (2012). Boko haram is local, yet global. Lagos: The Nation on Sunday.

Omokhunu, G. (2012). Boko Haram-Our learning environments have been desecrated. The Nation, 4.

Omotola, J. S. (2009). Beyond secularism: The shadow of religion on Nigerian democracy. In J. Adekunle, Ed., Religion in politics: Secularism and national integration in modern Nigeria (pp.81-98). Trenton, NJ: Africa World Press.

Omotosho, A. O (2004). Religious violence in Nigeria-the causes and solutions: An Islamist perspective. Uppsala: Swedish Missiological Theme, 15-31.

Orji, U. K. (2012). Nigeria in the eye of the storm. Saturday Sun, 71.

Pape, R. (2006). Dying to win: The strategic logic of suicide terrorism. 
New York: Random House.

Samir, Y. (2008). Understanding religious identity and the causes of religious violence. South Asian Journal of Peace Building, 1, 2-21.

Selengut, C. (2008). Sacred fury: Understanding religious violence.

Tanner, R. E. S. (2007). Violence and religion: Cross-cultural opinions and consequences. Concept Publishing Company.

Terence, F. (2004). God and violence in the old testament. Word \& World, 24, 24. The 1999 Federal Constitution of Nigeria, article 38, p. 39. Abuja: Federal Government Press.

Uche, O. C. O. (2007). Religion and violent conflicts in Africa. In Nigerian democracy, contributions to global democracy (p. 390). Awka:
University Press, Nnamdi Azikiwe University.

Vetter, H. J., \& Perlstein, G. R. (1990). Perspectives on terrorism. California: Brooks/Cole Publishing Company.

Wardlaw, G. (1989). Political terrorism. New York: Cambridge University Press.

Wellman, J., \& Tokuno, K. (2004). Is religious violence inevitable? Journal for the Scientific Study of Religion, 43, 291. http://dx.doi.org/10.1111/j.1468-5906.2004.00234.x

Wikipaedia, the Free Encyclopaedia (2012). Religious violence. http//www.wikipaedia.com 